\title{
The Resource Curse Hypothesis in Lao Economy
}

\author{
Soukvisan Khinsamone \\ Department of Japanese and Asian Studies \\ Saitama University, 255 Shimo-Okubo, Sakura-Ku \\ Saitama-Shi, Saitama, Japan 338-8570
}

Tel: 81-80-6625-8999, E-mail: khinsamone@yahoo.com

Received: April 27, 2017 Accepted: May 10, 2017 Published: May 22, 2017

doi:10.5296/jad.v3i2.11128 URL: https://doi.org/10.5296/jad.v3i2.11128

\begin{abstract}
The purpose of this paper is to investigate the adaptability of the resource curse hypothesis for Lao economy. The study verifies the two crowding-out logics that resource abundance would crowd out manufacturing activities and/or savings and investment, by examining their causalities and impulse responses in a vector auto-regression (VAR) model estimation. The estimation outcomes implied the existence of the resource curse in Lao economy: resource production has crowded out manufacturing activities through real exchange rate appreciation, thereby causing the Dutch Disease; and resource production has not contributed significantly to capital accumulation, thereby being not consistent with Hartwick-rule. The study contributed to the literature by verifying two kinds of crowding-out logics on the resource curse by applying a VAR model: the crowding-out of manufacturing activities as a sectoral allocation, and the crowding-out of savings and investment as an intertemporal allocation. The study might also be valuable to the policy makers, since it proposed a strategy for transforming Lao economic structure from "resource curse" to "resource blessing" by setting up some institutional framework to allocate resource revenues to infrastructure development.
\end{abstract}

Keywords: Lao economy, Resource curse, ASEAN, Vector auto-regression, Dutch Disease, Hartwick-rule 


\section{Introduction}

Lao people's Democratic Republic (thereafter, Lao PDR) has achieved 7.4 percent economic growth on the average since the 2000s, one of the fastest growth in the Southeast Asia (Note 1). At the same time, Lao PDR has graded up her economic status from "low income" to "lower middle income" since 2010, according to the World Bank Analytical Classifications. (Note 2) One of the driving forces of rapid Lao economic growth is said to be natural resource development such as hydropower and mining. In fact, the two sectors of hydropower and mining account for more than 10 percent of the total tax revenues, more than 60 percent of the total exports and around 20 percent of GDP, respectively, in 2014. (Note 3) In comparison with the other ASEAN economies, Lao PDR is the second largest country in terms of the share of mining and utility to GDP. (Note 4)

The most critical question for Lao economy is whether Lao economy sustain its growth by depending highly on natural resource development. This question reminds us of the "resource curse" problem: the economies with rich natural resource wealth tend to grow more slowly than resource-poor economies. Although the resource curse has been investigated from a variety of aspects, the central arguments in the context of economic perspective in the long run might be represented by the following two logics: natural resource abundance might crowd out manufacturing activities and/or savings and investment. These logics have been often referred to as the applicability of Dutch Disease and of Hartwick rule. Thus, it would be of great significance to diagnose Lao economy in a quantitative manner from the perspective of the resource curse. If some symptom of the resource curse were identified, Lao PDR should have a strategy to remove the source of disease in advance in order to ensure its sustainable growth.

This article aims to investigate the adaptability of the resource curse hypothesis for Lao economy by applying a vector auto-regression (VAR) model as a quantitative analytical method. The main focus is to verify the two crowding-out logics that resource abundance might crowd out manufacturing activities and/or savings and investment, by examining their causalities and impulse responses in a VAR framework.

The structure of this article is as follows. Section 2 represents literature review and clarifies the contribution of this study; Section 3 conducts empirics with a VAR model estimation; and the last section summarizes and concludes.

\section{Literature Review and Contribution}

This Section reviews the literature on the resource curse hypothesis including its mechanism and channels and also the literature on the application of the hypothesis to Lao economy, and then demonstrates this study's contributions.

\subsection{Resource Curse Hypothesis}

The resource curse hypothesis, initially proposed by Auty (1993), refers to the paradoxical phenomenon that economies with rich natural resource wealth tend to grow more slowly than resource-poor economies. It has been typically observed in the contrasting fact that many African economies with rich oil, diamonds or other minerals have stayed behind at the least developed income level, whereas East Asian economies have attained higher growth in the world without natural resources, during the post-world-war II period. 
The resource curse hypothesis has been put into a number of empirical studies, and the majority of them has provided supportive evidence (e.g., Sachs and Warner, 1995; Gelb, 1988; Gylfason et al., 1999; Manzano \& Rigobon, 2008). In line with the evidence above, Sachs and Warner (2001) argued that the empirical support for the resource curse is quite strong, by showing that there is little direct evidence that omitted geographical or climate variables explain the curse, or that there is a bias resulting from some other unobserved growth deterrent.

The experiences of resource rich economies have, however, been still heterogeneous, as typically seen in Chile and Botswana who have utilized their resources effectively to boost their economic performances. In fact, there has also been counter-evidence against the resource curse: Davis (1995) found no evidence of the natural resource curse, and Alexeev and Conrad (2009) showed that oil wealth and mineral wealth had even "positive" effects on income per capita, when controlling for a number of variables, particularly, dummies for East Asia and Latin America. The other impressive arguments have been presented by Van der Ploeg (2011), Mehlum et al. (2006) and Boschini et al. (2007). They argued that the "institutional quality" is a key factor to turn the resource curse into a blessing and that with good institutions the effect of resources on growth could be transformed from a curse to a blessing.

\subsection{Mechanism and Channels of Resource Curse}

This section investigates the mechanism and channels behind the solid fact of the resource curse. It has been argued that the curse is caused by a variety of factors: some related to political economy and governance and the others related to macroeconomic transmission channels. Regarding the aspects of political economy and governance, for instance, Collier and Hoeffler (2000) pointed out the risk that natural resource revenues would cause a country's conflict and strife, and Karl (1997) argued that the opportunities to access the rents associated with natural resources tend to induce government corruption.

The macroeconomic perspectives on resource curse are divided into short-term mechanism, and medium- and long- term one. The short-run mechanism on resource curse is often explained by the volatility of natural resource prices. Ramey and Ramey (1995), for example, offered evidence that the adverse growth effect of natural resources results mainly from volatility of commodity prices.

In discussing the medium- and long- term channels on resource curse, a logic of "crowding-out" proposed by Sachs and Warner (2001) has often been referred as in: natural resources crow-out activity $x$; activity $x$ drives growth; therefore natural resources harm growth. As there is a diversity of views regarding what drives growth, we have a similar diversity of views on the natural resource question. As far as purely economic issues are concerned, however, the leading explanations could be summarized into two kinds of crowding-out logics as follows. One is, natural resources crowd-out manufacturing activities from a sectoral perspective. The other is, natural resources crowd-out savings and investment from an intertemporal perspective.

\subsubsection{Dutch Disease Hypothesis}

The logic that natural resources crowd-out manufacturing activities is familiar as the Dutch 
Disease hypothesis. The Dutch Disease named by the Economist magazine on November 26, 1977 was originally inspired by side-effects of natural gas discoveries in the Northern Sea by the Netherlands in the late 1950s. The Disease was described as the negative impact on a country's economy due to large inflows of foreign income through the natural gas discovery. The logical processes were explained as follows: the foreign currency inflows lead to currency appreciation; it makes domestic products less price competitive in international market; it further causes the decline in the exports and production in manufacturing sectors.

The theoretical framework for the hypothesis was shown by the Salter-Swan-Corden-Dornbusch model. Corden and Neary (1982) originally described this model as follows: positive wealth shocks from natural resource sector, through raising higher disposal income and aggregate demand, trigger higher relative prices of non-tradable goods (spending effect) that correspond to a real exchange rate appreciation; this causes further movement of resources toward non-tradable sector away from tradable sector (resource movement effect).

The Dutch Disease hypothesis has been verified in terms of a real currency appreciation caused by a boom in oil or other mineral and agricultural commodities. Edwards (1986), for instance, verified the causality from a commodity export boom to a real exchange rate through money-inflation link. Sachs and Warner (2001) found that resource-rich economies tended to have higher price levels after controlling for the income effect, and demonstrated further that the subsequent loss of price competitiveness in manufacturing sectors impeded their export-led growth. More recent macroeconomic studies have also provided evidence directly to support the Dutch Disease effect. Harding and Venables (2013) indicated that the response to a resource windfall is to decrease non-resource exports by 35-70 percent, and Ismail (2010) revealed that a 10 percent oil windfall is on average associated with a 3.4 percent fall in value added across manufacturing sector.

\subsubsection{Hartwick Rule}

The second logic on whether natural resources crowd-out savings and investment could be evaluated by the criteria of the Hartwick rule (Hartwick, 1977). The rule holds that consumption can be maintained if the rents from nonrenewable resources are continuously invested rather than used for consumption. The economy, if its natural resources never crowd-out investment, can be said to follow the Hartwick rule, although many resource-rich developing countries in fact do not keep the rule. The World Bank (2011) quantified the crowding-out effects of natural resources on investment by comparing actual capital stocks with the hypothetical ones, i.e., the Hartwick rule counterfactual on what total capitals would be if countries had invested all the natural resource rents in produced capital. It represented the fact that the greater the dependence on natural resource rents, the greater the gap between actual capitals and hypothetical capitals. International Monetary Fund (2012) discussed the question of how much of resource windfall inflows to consume and how much to save/invest for resource-rich developing countries, and argued that a high saving/investment rate is necessary if there is to be a lasting impact on development, since the scaling up domestic investment would normally be a part of an optimal development strategy. 


\section{Macrothink}

\subsubsection{Theoretical Diagram for Crowding-out Logics}

This section tries to describe two kinds of crowding-out logics above in the theoretical frameworks presented by Corden and Neary (1982) and Bourdet and Falck (2006). The framework is, in brief, composed of "spending effect" and "resource movement effect" in the first crowding-out logic, i.e., Dutch Disease hypothesis from a sectoral aspect; and of "capital accumulation effect" in the second logic, i.e., Hartwick rule from an intertemporal aspect. Figure 1 depicts the frameworks by a diagram.

The first crowding-out logic, i.e., the Dutch Disease hypothesis is illustrated as follows. Non-tradables are indicated along with the horizontal axis and tradables along the vertical axis. The initial transformation curve between tradables and non-tradables is given by curve $\mathrm{P}-\mathrm{P}$. The initial equilibrium is given by point $\mathrm{A}$, where the transformation curve is tangential to the social indifference curve (not drawn) and the slope of the curves, i.e., the relative prices of non-tradables to tradables, is determined.

The production expansion of (tradable) resource sector shown at point $\mathrm{F}$ makes the transformation curve shift upwards to P-PF, since the supply of non-tradables is limited and the availability of tradables increases with higher disposal income. With unchanged prices of non-tradables shown at point A', there would be excess demand for non-tradables, assuming their positive income elasticity. Thus, the prices of non-tradables have to rise to clear the market, and since the prices of tradables are determined in the world market, the relative prices of non-tradables to tradables also rise, which corresponds to an appreciation of real exchange rate (spending effect). Then, the hike of relative prices, by encouraging a move of mobile production factors from the tradable sector to the non-tradable sector, causes an increase in the production of non-tradables and a decrease in that of non-resource tradables from point A' to point B (resource movement effect). 


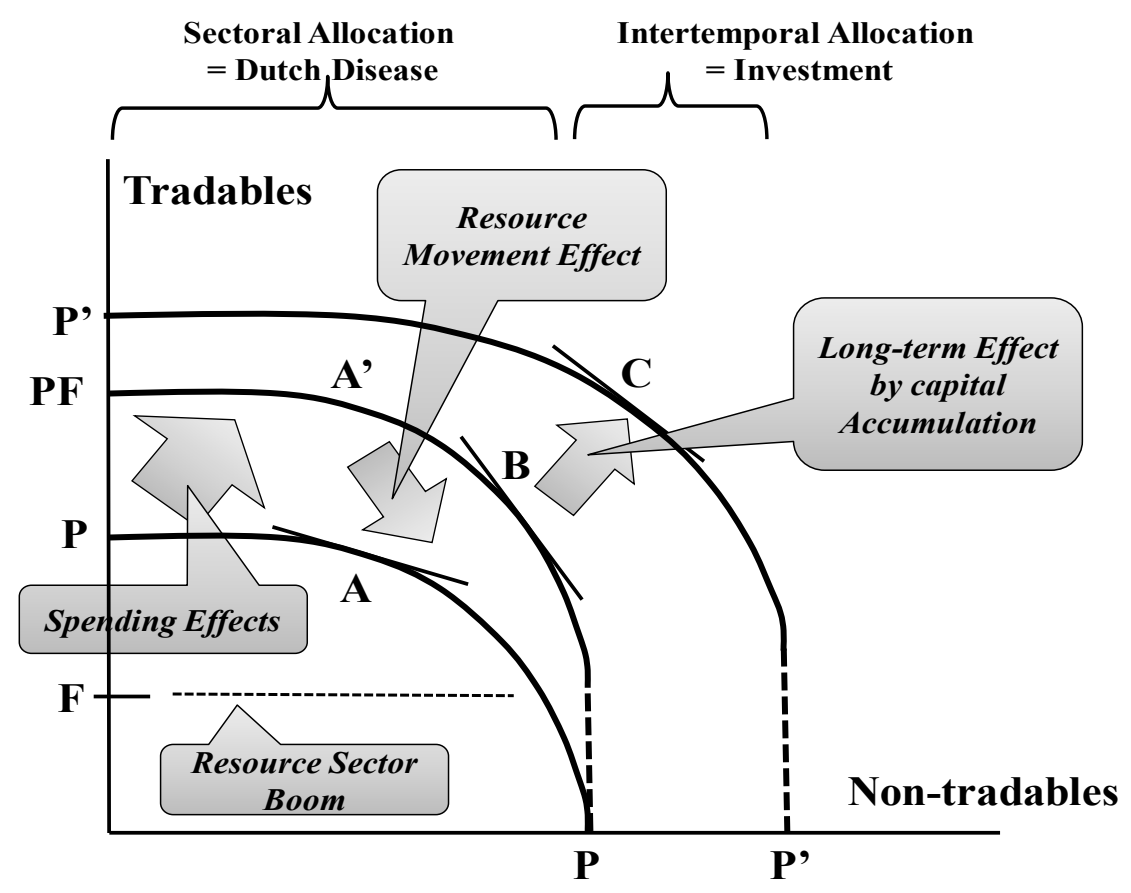

Figure 1. Theoretical Framework for Resource Curse

Note. This diagram is based on Corden and Neary (1982) and Bourdet and Falck (2006).

The second logic, i.e., Hartwick rule is illustrated as "capital accumulation effect" in an intertemporal allocation context. If an economy with the production expansion in resource sector would not crowd-out savings and investment, the transformation curve can shift out further towards P'-P', since the capital accumulation could be facilitated thereby expanding production frontier for both tradables and non-tradables. At this stage, the relative prices of non-tradables might be expected to fall from point $\mathrm{B}$ to point $\mathrm{C}$.

To sum up, from a sectoral dimension, the boom in resource sector might sacrifice the production of tradables (manufacturing) through real exchange rate appreciation under Dutch Disease. From an intertemporal dimension, however, this sectoral repercussion of the boom might be offset through capital accumulation, if savings and investment were not fully crowded out. It depends on to what extent an economy follows the Hartwick rule.

\subsection{Literature on Resource Curse in Lao Economy and Our Contributions}

This section first reviews the literature that applied the resource curse hypothesis to Lao economy. Although Lao economy depends highly on natural resource development, there have been limited studies focusing on Lao economy on resource curse hypothesis. All the studies as follows examined the adaptability of the resource curse to Lao economy from the perspective of Ditch Disease hypothesis. Kyophilavong and Toyoda (2009) and Kyophilavong et al. (2013), by using a macro-econometric model and a computable general equilibrium model respectively, investigated the impacts of capital inflows in resource sectors on Lao macro-economy. They found two-side effects: positive impacts in the short run, and negative effects in the long run - Dutch Disease effect through appreciation of real exchange rate. Insisienmay et al. (2015) searched for evidence of Dutch Disease by investigating the 
causal link from natural resource exports to real exchange rate, through estimating multiple regression equations. They found some symptoms of the disease - indirect spending effect but not resource movement effect, and proposed policy options such as the investments of resource revenues for infrastructure and education.

This study aims to examine the adaptability of resource curse hypothesis for Lao economy from different angles from the previous studies above. First, this study addresses not only Dutch Disease hypothesis but also Hartwick rule, by verifying two kinds of crowding-out logics in the long-term channels on resource curse: the crowding-out of manufacturing activities as a sectoral allocation, and the crowding-out of savings and investment as an intertemporal allocation.

Second, for an analytical method, this study adopts a vector auto-regression (VAR) estimation with Granger causality and impulse response tests. The VAR makes it possible to trace directly the causality and dynamic responsive effect from resource abundance to crowded-out variables. The causality issue would, in particular, be critical, since manufacturing activities, for instance, might also affect the share of natural resources to GDP. Suppose that manufacturing sectors in an economy boosts its economic growth for a while and makes the economy reach a high income stage. The economy would eventually appear to have a low share of natural resources to GDP. Similarly, the lack of manufacturing activities in an economy might make the economy stay at a resource-rich status. The crowding-out logics, therefore, require strict causality checks on whether resource abundance really crowds out growth-boosting activities.

In sum, the contributions of this study are to deal with the resource curse issue in Lao economy from both sectoral and intertemporal perspectives, and to analyze directly the causality and dynamic responsive effect from resource abundance to crowded-out variables under a VAR model framework.

\section{Empirics}

We herein turn to empirics to verify two kinds of crowding-out logics on resource curse by utilizing a VAR estimation method. We represent data for key variables, methodology of the estimation and estimation outcomes with their interpretation.

\subsection{Data for Key Variables}

As sample data, we target Lao PDR covering the annual period from 1980 to 2014. We identify the following five key variables for a VAR model estimation to examine the crowding-out logics on resource curse: mining and utility production (mup), manufacturing-services ratio (mos), investment-consumption ratio (ioc), inflation rate (cpi) and real GDP per capita $(y p c)$. The reason why we focus only on these limited number of variables is to maximize the degree of freedom in the estimation within the short-range of annual data for 1980 to 2014 .

The first variable of mining and utility production represents natural resource abundance in Lao economy. The data is retrieved from UNCTAD STAT. The database has the series of "Mining, manufacturing, utilities" and "Manufacturing" as GDP (value added) by kind of economic activity in terms of US dollars at constant prices (2005) in millions. The mining and utility production is calculated by subtracting "Manufacturing" from "Mining, 


\section{Macrothink}

manufacturing, utilities" in this series.

The second variable of manufacturing-services ratio is introduced for examining the "resource movement effect" in the first crowding-out logic, i.e., Dutch Disease hypothesis. The manufacturing sector is assumed to be a proxy of tradables, while the service sector is that of non-tradables in the theoretical framework. The manufacturing-services ratio is derived by dividing "manufacturing in value added share" by "services and construction in value added share", both of which are retrieved from UNCTAD STAT in the category of GDP by kind of economic activity.

The third variable of investment-consumption ratio is for investigating the "capital accumulation effect" in the second logic, i.e., the Hartwick rule. The ratio is produced by dividing "gross fixed capital formation" by "final consumption expenditure", both of which are also retrieved from UNCTAD STAT in the category of GDP by type of expenditure.

The fourth variable, i.e., inflation rate is assumed to be a proxy of real exchange rate, which is a variable for seeing the "spending effect" in the first crowding-out logic, i.e., Dutch Disease hypothesis. The reason for not using exchange rate is that Lao PDR has adopted "Crawling band around US dollar" as its currency regime during sample period, according to Ilzetzki et al. (2011). Frankel (2010) argued in the context of Dutch Disease that the real appreciation in the currency takes the form of nominal currency appreciation if the country has a floating exchange rate, whereas taking the form of money inflows and inflation if the country has a fixed exchange rate. Since the Lao currency regime is closer to a fixed one, we use inflation rate as a proxy of real exchange rate by following the argument of Frankel (2010). The data for inflation rate is taken from World Economic Outlook Database October 2016 of International Monetary Fund as the series of "average consumer prices, Dec. $2005=100 "$.

The last variable, i.e., real GDP per capita is included as a control variable in a VAR model estimation, since the manufacturing-services ratio might also be affected by development stage of an economy, for instance, according to the Petty-Clark's Law (Clark, 1940). The data for real GDP per capita is retrieved from UNCTAD STAT as the series of "GDP per capita, US Dollars at constant prices (2005) and constant exchange rate (2005)".

Figure 2 simply displays the five key variables above. We cannot judge any relationships such as causality and dynamic impacts from simple observation among variables, since the variables are interacting each other. There comes the necessity to conduct a VAR model estimation in the next section. 


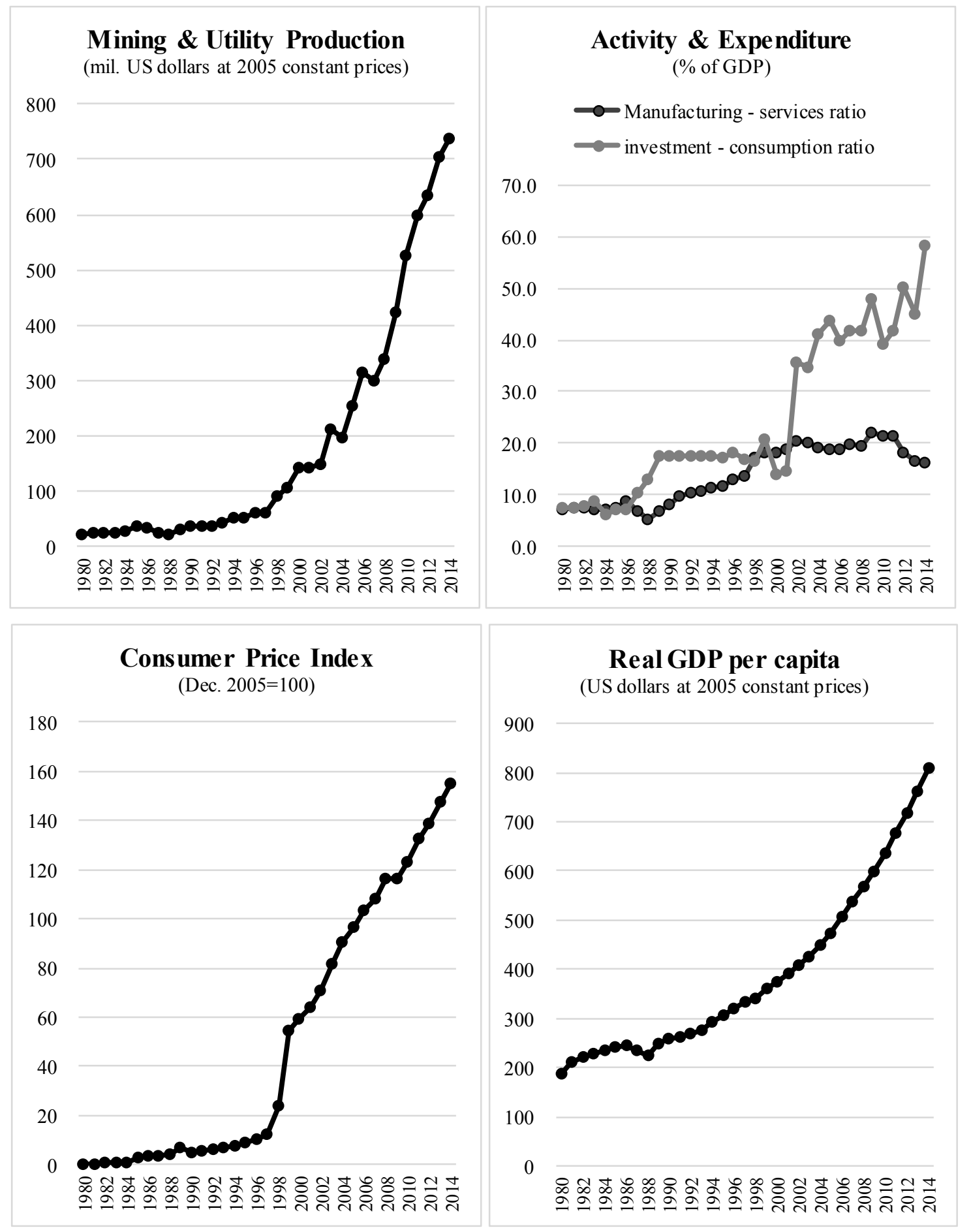

Source: UNCTAD STAT and World Economic Outlook Database October 2016 of International Monetary Fund (for Consumer Price Index)

Figure 2. Overview of Key Variables

\subsection{Methodology for a VAR Model Estimation}

We herein conduct a VAR model estimation. The reason why we adopt a VAR model for resource curse analysis is that the VAR model allows for potential and highly-likely 
endogeneity between the variables of interest, and also for tracing out the dynamic responses of variables to exogenous shocks overtime. The specific purpose of a VAR model estimation here is to examine the Granger causalities and the impulse responses from resource production to manufacturing-services ratio for identifying the Dutch Disease crowding-out logic (thereafter, Dutch Disease analysis), and those from resource production to investment-consumption ratio for investigating the adaptability of Hartwick-rule (thereafter, Hartwick-rule analysis), with a focus on Lao economy.

\subsubsection{Data Property}

Before specifying a VAR model, we investigate the stationary property of each endogenous variable's data, by employing a unit root test, and if needed, a co-integration test for a set of variables' data. The unit root test is conducted on the null hypothesis that a level and/or a first difference of the individual data have a unit root. In case that the unit root test tells us that each variable' data are not stationary in the level, but stationary in the first-difference, a set of variables' data correspond to the case of I(1), and then can be further examined by a co-integration test for the "level" data. If a set of variables' data are identified to have a co-integration, the use of the "level" data is justified for a VAR model estimation. For a unit root test, we adopt the augmented Dickey-Fuller (ADF) test (see Said \& Dickey, 1984), and for a co-integration test, we employ the Johansen test (see Johansen, 1995). The both tests are conducted by including "trend and intercept" in the test equation.

Table 1 reports the result of both unit root and co-integration tests. For the data of all four endogenous variables, the unit root test identified a unit root in their levels, but rejected it in their first differences at the conventional level of significance, thereby the variables following the case of $I(1)$. The co-integration test was, thus, conducted further on the combination of variables for Dutch Disease analysis and for Hartwick-rule analysis, and both the trace test and the Maximum-eigenvalue test implied that the level series of a set of variables' data were co-integrated. We thus utilize the level data for a VAR model estimation.

Table 1. ADF Unit Root Test and Johansen Co-integration Test

\begin{tabular}{ccccc}
\hline \hline & \multicolumn{2}{c}{ Unit Root Test (ADF Test) } & \multicolumn{2}{c}{ Cointegration Test (Johansen Test) } \\
\cline { 2 - 4 } & Level & First Difference & Trace & Max-eigen \\
\hline \multicolumn{2}{l}{ For Dutch Disease Analysis } & & & \\
mup & 3.75 & $-5.54 * * *$ & $35.90^{* * *}$ & $28.52^{* * *}$ \\
mos & -0.49 & $-4.18^{* *}$ & & \\
cpi & -1.50 & $-4.35^{* * *}$ & & $14.25^{*}$ \\
\hline For Hartwick-rule Analysis & & $17.39 * *$ & \\
mup & 3.75 & $-5.54 * * *$ & & \\
ioc & -2.65 & $-7.13 * * *$ & & \\
\hline \hline
\end{tabular}

Note. $* * *, * *, *$ denote rejection of null hypothesis at the $99 \%, 95 \%$ and $90 \%$ level of significance, respectively. 
3.2.2 Model Specification

We now specify a VAR model for estimation in the following way.

$$
y_{t}=\mu t+v_{1} y_{t-1}+a_{t}
$$

where $y_{t}$ is a $(3 \times 1)$ column vector of the endogenous variables with year $t$, i.e., $y_{t}=\left(\operatorname{mutp}_{t} \operatorname{mos}_{t} c p l_{t}\right)^{l}$ for the Dutch Disease analysis, and a $(2 \times 1)$ column vector, $y_{t}=\left(\operatorname{mup}_{t} t a c_{t}\right)^{2}$ for Hartwick-rule analysis, $\mu$ is a constant vector, $V_{1}$ is a coefficient matrix, $y_{t-1}$ is a vector of the lagged endogenous variables, and $\varepsilon_{t}$ is a vector of the random error terms in the system. In the Dutch Disease model, we insert a vector of the control variable of real GDP per capita $(y p c)$, since manufacturing-services ratio might be also affected by development stages of an economy as mentioned before. The lag length $(-1)$ is selected by the minimum Akaike Information Criterion (AIC) with maximum lag equal to $(-2)$ under the limited number of observations.

Based on the VAR model (1), for the Dutch Disease analysis, we examine the Granger causality among natural resource production (тир), inflation rate (cpi) and manufacturing-services ratio (mos), and the impulse responses of cpi and mos to the mup shock so that we can trace the 8-year dynamic effects. If the causality and impulse response from mup to cpi and mos were identified (positively to cpi and negatively to mos), we could then argue that Lao economy has suffered from Dutch Disease. Regarding the Hartwick-rule analysis, we investigate the causality between natural resource production (тир) and investment-consumption ratio (ioc), and the impulse responses of ioc to the mup shock. When the causality and impulse response from mup to ioc were confirmed in positive ways, we could speculate that resource production would not crowd out savings and investment, and that Lao economy would move towards the Hartwick-rule.

\subsection{Estimation Outcomes and Discussion}

Table 2, Table 3 and Figure 3 respectively report estimation outcomes of the estimated VAR model, the Granger causalities and the impulse responses.

In the Dutch Disease analysis, the Granger causality test in Table 3 identified the causality from natural resource production (mup) to both of inflation rate (cpi) and manufacturing-services ratio (mos) at 95 significance level. Considering the estimated VAR model in Table 2, the causality from resource production ( supposed to be in positive way, whereas the one from resource production (тир) to manufacturing-services ratio (mos) is in negative way. These causality results bring us to the test of impulse responses of inflation rate (cpi) and manufacturing-services ratio (mos) to the shock of resource production (mup). Figure 3 showed that inflation rate (cpi) positively responded to the shock of resource production ( three-year lags, whereas manufacturing-services ratio (mos) negatively responded to that shock after five-year lags.

In the Harttwick-rule analysis, the causality test in Table 3 verified the causality from natural resource production ( causality at more than 95 significance level. Looking at the estimated VAR model in Table 2, this causality is supposed to be in positive way. The impulse response of 
investment-consumption ratio (ioc) to the shock of resource production (mup) in Figure 3, however, was insignificant within a 95 percent error band in the 8-year dynamic effect.

The implications of the estimation outcomes above are summarized as follows. Regarding the applicability of the Dutch Disease hypothesis, we could argue that in Lao economy resource production would crowd out manufacturing activities through real exchange rate appreciation, thereby causing the Dutch Disease. In the analysis of Hartwick-rule, we could not get a clear-cut estimation outcome: resource production would not seem to crowd out savings and investment, but at the same time might not contribute significantly to capital accumulation, thereby being not consistent with Hartwick-rule in Lao economy.

Then, what kinds of policy messages would be extracted from the estimation outcomes above? The estimation outcomes imply the existence of "resource curse" in Lao economy. On the other hand, Lao economy that has entered middle income stage since 2010 will encounter the danger of "middle income trap" sooner or later. Under this narrow path, the key strategy for Lao economy is to transform its economic structure from "resource curse" to "resource blessing": the fruits of natural resource production should be utilized effectively for sustainable economic growth. In this context, Van der Ploeg (2011) argued that "good institution" makes it possible to turn the resource effect from a curse to a blessing. As far as we see the institutional quality by the Worldwide Governance Indicators by the World Bank in Figure 4, the quality of Lao PDR is behind that of the world average and even the average of ASEAN. The index takes the value of -2.5 in the worst quality and of 2.5 in the best one, and the value of around zero in the world average. We could observe that all the indexes for "control of corruption", "government effectiveness", "rule of law", "regulatory quality" and "voice \& accountability" except the one for "political stability and absence of violence" in Lao PDR are negative and even lower than those of the ASEAN average.

Then, the next question is how to improve institutional quality of Lao PDR, to be more specific, how to materialize the institution to enable its economy to turn the resource effect from a curse to a blessing. There would be a need to establish an institutional framework to utilize resource revenues for the development projects to enhance and sustain economic growth. Demachi and Kinkyo (2014) introduced some advanced experiences of such middle incomers as Indonesia and Malaysia: Indonesia directed its oil revenues to rural infrastructure, in particular, to implementing large-scale projects for school construction, in the 1970s; and Malaysia achieved resource-based industrialization by directly allocating natural resource revenue to investment in heavy industries. Lao economy, by getting the good lessons from forerunners, should set up some institutional framework to allocate resource revenues to infrastructure development for facilitating non-resource manufacturing activities and for contributing to capital accumulation in the manufacturing sectors. 
Table 2. Estimated VAR Model

\begin{tabular}{|c|c|c|c|}
\hline Dutch Disease analysis & mup & cpi & mos \\
\hline \multirow{2}{*}{ mup -1 } & $0.960 * * *$ & $0.054 * *$ & $-0.011 * *$ \\
\hline & {$[9.032]$} & {$[2.456]$} & {$[-2.113]$} \\
\hline \multirow{2}{*}{ cpi-1 } & 0.502 & $0.860 * * *$ & 0.016 \\
\hline & [1.491] & {$[12.337]$} & {$[1.006]$} \\
\hline \multirow{2}{*}{$\operatorname{mos}-1$} & -0.242 & $1.564 * * *$ & $0.876 * * *$ \\
\hline & {$[-0.114]$} & {$[3.547]$} & [8.238] \\
\hline \multirow{2}{*}{$y p c$} & 0.127 & $-0.315 * * *$ & $0.050 *$ \\
\hline & {$[0.230]$} & {$[-2.758]$} & [1.827] \\
\hline adj. $R^{\wedge} 2$ & 0.988 & 0.992 & 0.956 \\
\hline "Hartwick-rule analysis & \multicolumn{2}{|c|}{ mup } & $i O c$ \\
\hline \multirow{2}{*}{ mup -1 } & \multicolumn{2}{|c|}{$0.994 * * *$} & $0.020 * *$ \\
\hline & \multicolumn{2}{|c|}{$[27.377]$} & {$[2.341]$} \\
\hline \multirow{2}{*}{ ioc -1} & \multicolumn{2}{|c|}{$1.634 * * *$} & $0.756^{* * *}$ \\
\hline & \multicolumn{2}{|c|}{ [3.297] } & {$[6.348]$} \\
\hline \multirow{2}{*}{$C$} & \multirow{2}{*}{\multicolumn{2}{|c|}{$-16.650 * *$}} & $3.759 *$ \\
\hline & & {$[-2.084]$} & [1.958] \\
\hline $\operatorname{adj} . R^{\wedge} 2$ & \multicolumn{2}{|c|}{0.990} & 0.890 \\
\hline
\end{tabular}

Note. $* * *, * *, *$ denote rejection of null hypothesis at the $99 \%, 95 \%$ and $90 \%$ level of significance, respectively. The figure in [ ] are t-value.

Table 3. Granger Causality Test

\begin{tabular}{|c|c|c|c|}
\hline Dutch Disease analysis & Lags & Null Hypothesis & Chi-sq \\
\hline \multirow{2}{*}{ mup \& cpi } & \multirow{2}{*}{1} & mup does not Granger Cause $c p i$ & $6.036 * *$ \\
\hline & & $c p i$ does not Granger Cause mup & 2.223 \\
\hline \multirow{2}{*}{ mup \& mos } & \multirow{2}{*}{1} & mup does not Granger Cause mos & $4.467 * *$ \\
\hline & & mos does not Granger Cause mup & 0.013 \\
\hline Hartwick-rule analysis & Lags & Null Hypothesis & Chi-sq \\
\hline \multirow{2}{*}{ mup \& ioc } & \multirow{2}{*}{1} & mup does not Granger Cause ioc & $5.484 * *$ \\
\hline & & ioc does not Granger Cause mup & $10.872 * * *$ \\
\hline
\end{tabular}

Note. $* * *, * *, *$ denote rejection of null hypothesis at the $99 \%, 95 \%$ and $90 \%$ level of significance, respectively. 

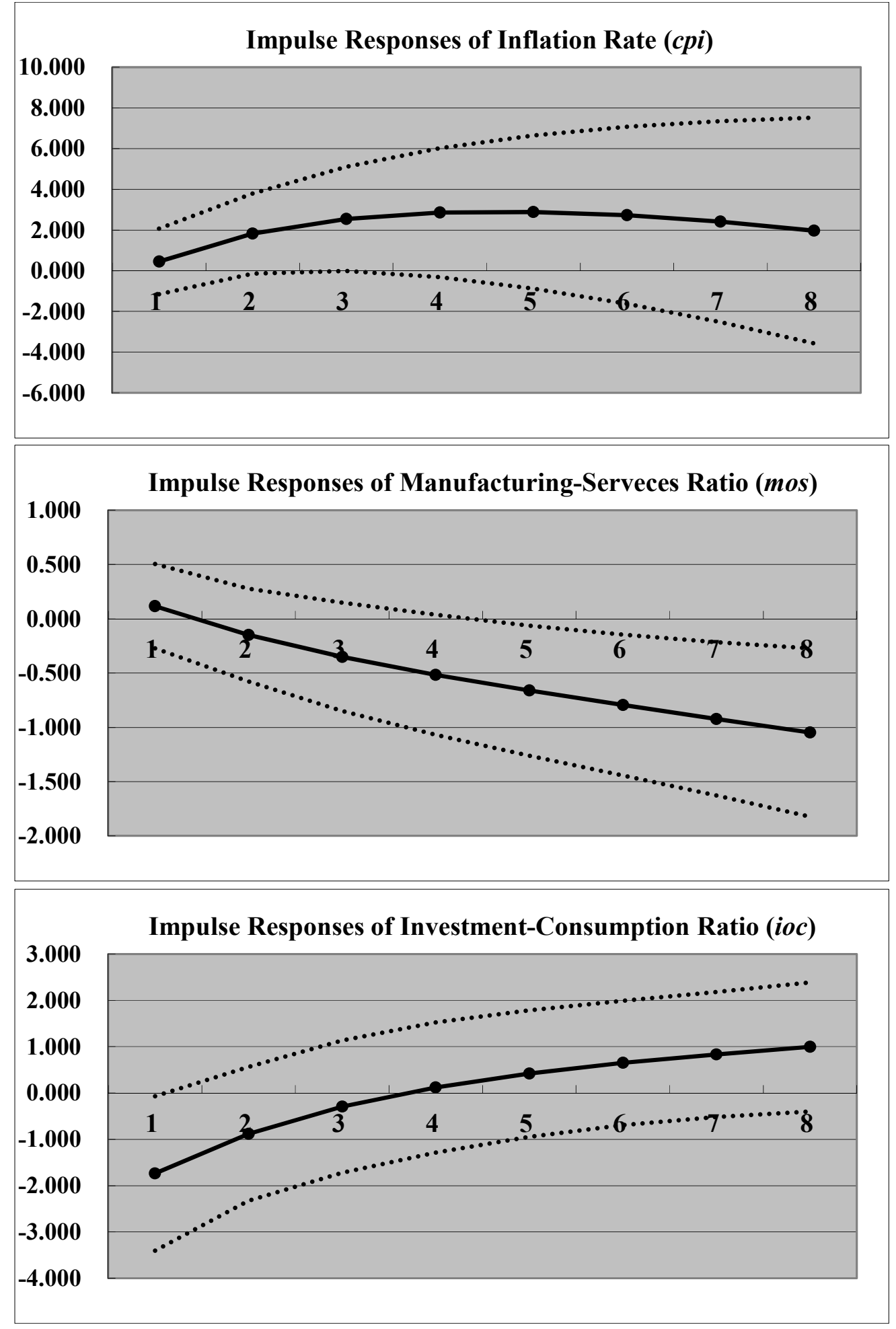

Note. The dotted lines represent a 95 percent error band over 8-year horizons.

Figure 3. Impulse Responses to Shock of Resource Production 


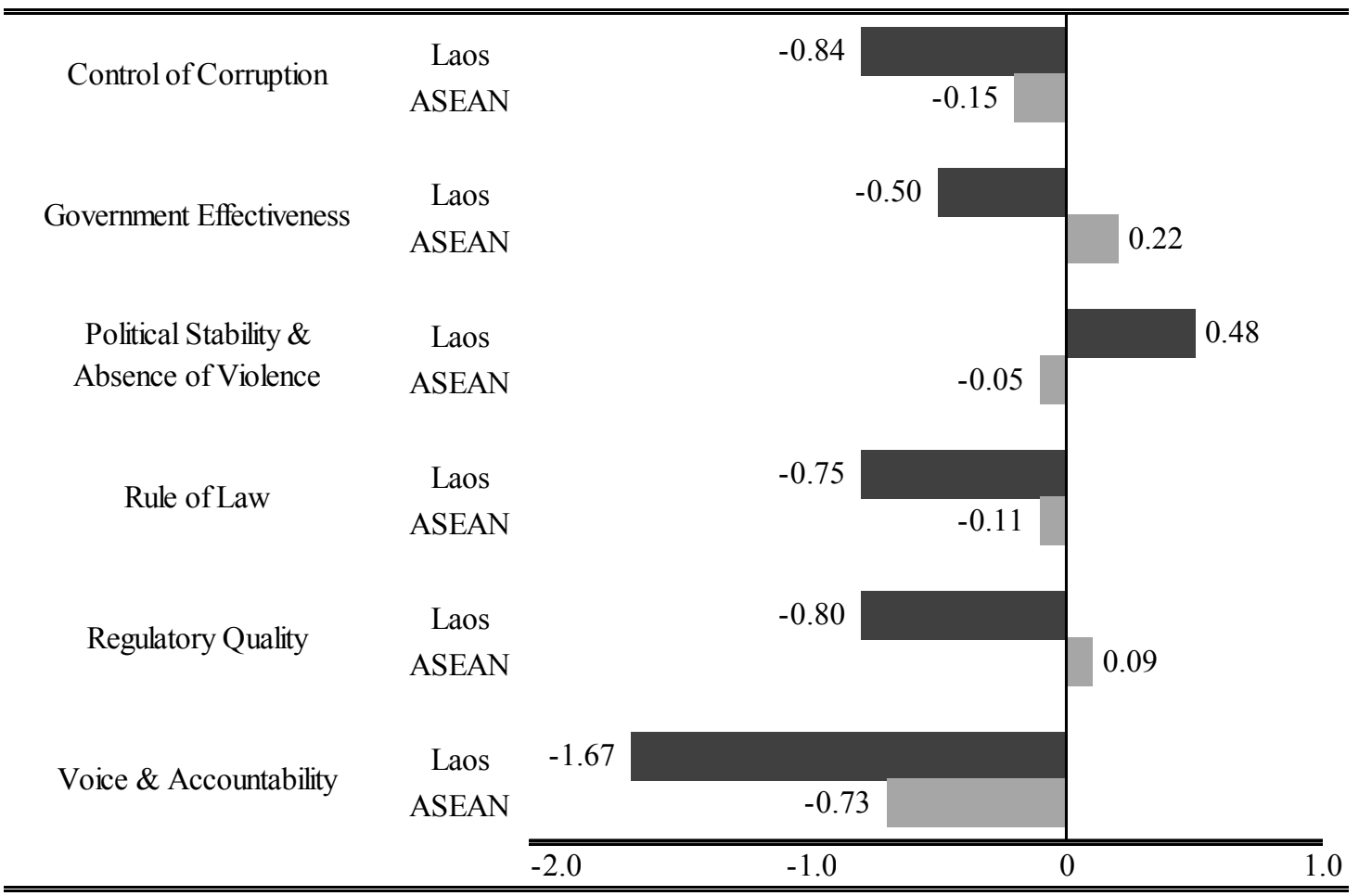

Source: Worldwide Governance Indicators by the World Bank

Figure 4. Worldwide Governance Indicators in Lao PDR and ASEAN in 2015

\section{Concluding Remarks}

This article investigated the adaptability of the resource curse hypothesis for Lao economy by applying a VAR model as an analytical method. The main focus was to verify the two crowding-out logics that resource abundance would crowd out manufacturing activities and/or savings and investment, by examining their causalities and impulse responses in a VAR framework. The estimation outcomes implied the existence of "resource curse" in Lao economy: resource production has crowded out manufacturing activities through real exchange rate appreciation, thereby causing the Dutch Disease; and resource production has not contributed significantly to capital accumulation, thereby being not consistent with Hartwick-rule.

The strategic policy implications of this study is the significance in transforming Lao economic structure from "resource curse" to "resource blessing" to sustain its economic growth in its middle income stage. For that purpose, Lao economy, by getting the good lessons from forerunners such as Indonesia and Malaysia, should set up some institutional framework to allocate resource revenues to infrastructure development for facilitating non-resource manufacturing activities and for contributing to capital accumulation in the manufacturing sectors. 


\section{Macrothink}

Journal of Asian Development

ISSN 2377-9594

2017, Vol. 3, No. 2

\section{References}

Alexeev, M., \& Conrad, R. (2009). The elusive curse of oil. The Review of Economics and Statistics, 91(3), 586-598. https://doi.org/10.1162/rest.91.3.586

Auty, R. (1993). Sustaining Development in Mineral Economies: The Resource Curse Thesis. Oxford University Press, New York.

Boschini, A. D., Pettersson, J., \& Roine, J. (2007). Resource Curse or Not: A Question of Appropriability. Scandinavian Journal of Economics, 109(3), 593-617. https://doi.org/10.1111/j.1467-9442.2007.00509.x

Bourdet, Y., \& Falck, H. (2006). Emigrants' Remittances and Dutch Disease in Cape Verde. International Economic Journal, 267-284. http://dx.doi.org/10.1080/10168730600879323

Clark, C. (1940). The Conditions of Economic Progress. Macmillan, New York.

Collier, P., \& Hoeffler, A. (2000). Greed and Grievance in Civil War. Policy Research Paper (The World Bank) No. 2355. https://doi.org/10.1596/1813-9450-2355

Corden, W. M., \& Neary, J. P. (1982). Booming sector and de-industrialization in a small open economy. The economic journal, 92(368), 825-848. https://doi.org/10.2307/2232670

Davis, G. A. (1995). Learning to love the Dutch disease: Evidence from the mineral $\begin{array}{lll}\text { economies. } \quad \text { World } & \text { 23(10), } & \text { 1765-1779. }\end{array}$ https://doi.org/10.1016/0305-750X(95)00071-J

Demachi, K., \& Kinkyo, T. (2014). Macroeconomic Management in Resource-Rich Developing Economies. $\quad$ Kokuminkeizaizassi, 210(3), 55-67. https://doi.org/10.1142/9789814713405_0009

Edwards, S. (1986). A Commodity Export Boom and the Real Exchange Rate: The Money-Inflation Link. MIT Press, Cambridge.

Frankel, J. A. (2010). The natural resource curse: a survey (No. w15836). National Bureau of Economic Research. https://doi.org/10.2139/ssrn.1565588

Gelb, A. H. (1988). Windfall Gains: Blessing or Curse?, Oxford University Press, New York.

Gylfason, T., Herbertsson, T. T., \& Zoega, G. (1999). A mixed blessing. Macroeconomic dynamics, 3(2), 204-225. https://doi.org/10.1017/S1365100599011049

Harding, T., \& Venables, A. J. (2013). The Implications of Natural Resource Exports for Non-Resource Trade. OxCarre Research 103. https://www.oxcarre.ox.ac.uk/files/OxCarreRP2013103.pdf

Hartwick, J. M. (1977). Intergenerational equity and the investing of rents from exhaustible resources. The american economic review, 67(5), 972-974. http://www.jstor.org/stable/1828079 
Ilzetzki, E., Reinhart, C. M., \& Rogoff, K. S. (2011). The country chronologies and background material to exchange rate arrangements into the 21st century: Will the anchor currency hold. Retrieved from http://personal.lse.ac.uk/ilzetzki/data/ERACountry_Chronologies_2011.pdf.

Insisienmay, S., Nolintha, V., \& Park, I. (2015). Dutch disease in the Lao economy: Diagnosis and treatment. International Area Studies Review, 18(4), 403-423. https://doi.org/10.1177/2233865915595155

International Monetary Fund. (2012). Macroeconomic Policy Frameworks for Resource-Rich Developing Countries, International Monetary Fund. Retrieved from https://www.imf.org/external/np/pp/eng/2012/082412.pdf

Ismail, K. (2010). The Structural Manifestation of the 'Dutch Disease': The Case of Oil Exporting Countries. International Monetary Fund Working Paper, 10/103. https://doi.org/10.5089/9781455200627.001

Johansen, S. (1995). Likelihood-based Inference in Cointegrated Vector Autoregressive Models. Oxford University Press, New York. https://doi.org/10.1093/0198774508.001.0001

Karl, T. L. (1997). Paradox of Plenty. University of California Press, Berkeley and Los Angeles.

Kyophilavong, P., \& Toyoda, T. (2009). Foreign capital inflows in the natural resources sector: Impacts on the Lao economy. International Seminar on Skills Development for the Emerging New Dynamism in Asian Developing Countries under Globalization. The First Annual Conference of the University Network for Development in Asia (UNDA), Pathumwan Princess Hotel, Bangkok, Thailand, January 23-25, 2009.

Kyophilavong, P., Senesouphap, C., \& Yawdhacksa, S. (2013). Resource Boom, Growth and Poverty in Laos: What Can We Learn from Other Countries and Policy Simulations? PEP (Partnership for Economic Policy) Working Paper, No. 2013-05.

Manzano, O., \& Rigobon, R. (2008). Resource Curse or Debt Overhang. National Bureau of Economic Research Working Paper, No. 8390.

Mehlum, H., Moene, K., \& Torvik, R. (2006). Institutions and the Resource Curse. Economic Journal, 116, 1-20. https://doi.org/10.1111/j.1468-0297.2006.01045.x

Sachs, J D., \& Warner, A. M. (1995). Natural Resource Abundance and Economic Growth. https://doi.org/10.3386/w5398

Sachs, J. D., \& Warner, A. M. (2001). The curse of natural resources. European Economic Review, 45(4-6), 827-838. https://doi.org/10.1016/S0014-2921(01)00125-8

Said, S. E., \& Dickey, D. A. (1984). Testing for Unit Roots in Autoregressive-Moving Average Models of Unknown Order. Biometrika, 71(3), 599. https://doi.org/10.2307/2336570

Ramey, G.. \& Ramey, V. A. (1995). Cross-Country Evidence on the Link between Volatility and Growth. American Economic Review, 85(5), 138-1151. 


\section{Macrothink}

Journal of Asian Development

ISSN 2377-9594 2017, Vol. 3, No. 2

Van der Ploeg, F. (2011). Natural resources: Curse or blessing?. Journal of Economic Literature, 49(2), 366-420. https://doi.org/10.1257/jel.49.2.366

World Bank. (2011). The Changing Wealth of Nations: Measuring Sustainable Development in the New Millennium, the World Bank. https://doi.org/10.1596/978-0-8213-8488-6

\section{Notes}

Note 1. The growth rate is based on World Development Indicators by the World Bank.

Note 2. See https://datahelpdesk.worldbank.org/knowledgebase/articles/378834-how-does -the-world-bank-classify-countries

Note 3. The figures are based on Lao Statistical Bureau, Government of Lao PDR.

Note 4. According to UNCTAD STAT, the shares of mining and utility to GDP in 2014 among ASEAN are $49.0 \%$ in Brunei, $18.1 \%$ in Lao PDR, $15.7 \%$ in Vietnam, $12.3 \%$ in Malaysia, $11.3 \%$ in Indonesia, $8.7 \%$ in Myanmar, $6.6 \%$ in Thailand, $4.3 \%$ in Philippines, $1.8 \%$ in Cambodia, and $1.4 \%$ in Singapore.

\section{Copyright Disclaimer}

Copyright for this article is retained by the author(s), with first publication rights granted to the journal.

This is an open-access article distributed under the terms and conditions of the Creative Commons Attribution license (http://creativecommons.org/licenses/by/4.0/). 